\title{
PENERAPAN MODEL PETA PIKIRAN (MIND MAPPING) UNTUK MENINGKATKAN KETERAMPILAN MENULIS KARANGAN NARASI SISWA KELAS IVB SD NEGERI 007 BANGKINANG
}

\author{
Iis Aprinawati \\ Surel : aprinawatiiis@gmail.com
}

\begin{abstract}
This study aims to describe the improvement of students' writing skills narrative grade IVB SDN 007 Bangkinang. The subjects of this study were the students of the IVB class which amounted to 22 people. The data collection techniques used in this research were documentation, observation, and test. Based on the results of this study can be concluded that writing the narrative essay of students is good, from 22 students only 17 students or $77.27 \%$ who achieve mastery individually. The result of writing the narrative essay of students in cycle II is also quite good with an average of 82.54 and from 22 students there are 19 students or $86.36 \%$ who achieve mastery individually. Thus it can be concluded that the application of Mind Mapping model can improve can improve the writing skills skill of students' narrative class IVB SDN 007 Bangkinang.
\end{abstract}

Keyword : Model Mind Mapping, Result Of Skill Write, Composition Of Narasi

\begin{abstract}
ABSTRAK
Penelitian ini bertujuan untuk mendiskripsikan peningkatan keterampilan menulis karangan narasi siswa kelas IVB SDN 007 Bangkinang. Subjek penelitian ini adalah siswa kelas IVB yang berjumlah 22 orang. Teknik pengumpulan data yang digunakan dalam penelitian ini adalah teknik dokumentasi, observasi, dan tes. Berdasarkan hasil penelitian disimpulkan bahwa menulis karangan narasi siswa tergolong baik, dari 22 siswa hanya 17 siswa atau 77,27\% mencapai ketuntasan secara individual. Hasil menulis karangan narasi siswa pada siklus II juga tergolong baik dengan rata-rata 82,54 dan dari 22 siswa terdapat 19 siswa atau 86,36\% mencapai ketuntasan secara individual. Dengan demikian dapat disimpulkan bahwa penerapan model Mind Mapping dapat meningkatkan dapat meningkatkan hasil keterampilan menulis karangan narasi siswa kelas IVB SDN 007 Bangkinang.
\end{abstract}

Kata Kunci : Model Mind Maping, Kemampuan Menulis, Karangan Narasi

\section{PENDAHULUAN}

Berdasarkan

Kompetensi dan Kompetensi Dasar

Tingkat SD/MI dalam peraturan
Menteri Pendidikan Nasional nomor 22 Tahun 2006 tentang standar isi untuk satuan pendidikan sekolah dasar, bahasa memiliki peran sentral 
dalam perkembangan intelektual, sosial, dan emosional peserta didik, dan merupakan penunjang keberhasilan dalam mempelajari semua bidang studi. Pembelajaran bahasa diharapkan membantu peserta didik mengenal dirinya, budayanya, dan budaya orang lain, mengemukakan gagasan dan perasaan, berpartisipasi dalam masyarakat yang menggunakan bahasa tersebut, dan menemukan serta menggunakan kemampuan analitis dan imajinatif yang ada dalam dirinya.

Mata pelajaran bahasa Indonesia bertujuan agar peserta didik mempunyai kemampuan sebagai berikut: (1) berkomunikasi secara efektif dan efisien sesuai dengan etika yang berlaku, baik secara lisan maupun tertulis, (2) menghargai bahasa dan bangga menggunakan bahasa Indonesia sebagai bahasa persatuan dan bahasa negara, (3) memahami bahasa Indonesia dan menggunakannya dengan tepat dan kreatif untuk berbagai tujuan, (4) menggunakan bahasa Indonesia untuk meningkatkan kemampuan intelektual, serta kematangan emosional dan sosial, (5) menikmati dan memanfaatkan karya sastra untuk memperluas wawasan, memperhalus budi pekerti, serta meningkatkan pengetahuan dan kemampuan berbahasa, dan (6) menghargai dan membanggakan sastra Indonesia sebagai khazanah budaya dan intelektual manusia Indonesia.
Menurut (Rich, 2008:2) Kemampuan yang paling menentukan keberhasilan siswa sebelum tahun-tahun sekolah dasar adalah bergerak melampaui dasar untuk membangun kemampuan sebagai pembelajar yang kuat.

Berdasarkan observasi yang dilakukan oleh peneliti, kenyataan dilapangan khususnya pada pembelajaran bahasa Indonesia di SD Negeri 007 Bangkinang bahwa hasil keterampilan menulis karangan pada mata pelajaran bahasa Indonesia siswa kelas IVB masih tergolong rendah. Ketetapan nilai kriteria ketuntasan minimum (KKM) bagi siswa mata pelajaran bahasa Indonesia adalah 75. Ternyata dalam pembelajaran bahasa Indonesia ini masih banyak siswa yang belum bisa menempuhnya. Dari 22 siswa terdapat 9 orang siswa yang tuntas dan 13 orang yang belum mencapai nilai KKM.

Rendahnya hasil keterampilan menulis karangan bahasa Indonesia yang diperoleh siswa kelas IVB SD Negeri 007 Bangkinang disebabkan karena dalam mengajar mata pelajaran bahasa Indonesia guru kurang memberikan variasi dalam menerapkan model-model pembelajaran yang kurang menarik minat dan motivasi siswa dalam mengikuti pembelajaran.

Berdasarkan permasalahan maka seorang guru dituntut untuk melakukan perbaikan dalam pembelajaran, khususnya pada mata pelajaran bahasa Indonesia, maka 
penulis sebagai peneliti mencoba melakukan usaha perbaikan yaitu dengan cara memlih salah satu model pembelajaran yang tepat yang dapat mengaktifkan siswa sehingga hasil keterampilan menulis karangan dapat meningkat, siswa menganggap mata pelajaran bahasa Indonesia sulit untuk dipahami pada kegiatan menulis, terutama menulis narasi, siswa kesulitan dalam mengungkapkan ide dan imajinasinya dalam bentuk tulisan.

Berdasarkan dari permasalahan tersebut, maka perlu adanya pemilihan model pembelajaran yang tepat. Model pembelajaran tersebut adalah model yang dapat menghubungkan ide-ide atau pokok pikiran cerita, sehingga siswa merasa mudah untuk menulis suatu cerita. Dengan begitu maka kemampuan menulis cerita siswa akan meningkat. Salah satu model yang dapat menghubungkan ide-ide dan pokok pikiran suatu cerita secara nyataadalah model Mind Mapping. Menurut (Imas dan Berlin, 2015:53)“ Mind Mapping merupakan alat yang dapat membantu otak berpikir secara teratur, dan mampu memetakan pikiran dalam bentuk simbolsimbolnyata". Berdasarkan pengertian di atas dapat disimpulkan bahwa dengan model Mind Mapping siswa mudah dalam menyusun ide-ide dan pikiran pokok tentang cerita yang akan ditulisnya.

Dengan demikian, proses mencurahkan ide dan menghubungkan ide-ide dalam bentuk cerita akan lebih mudah. Maka dari itu berdasarkan latar belakang di atas maka peneliti tertarik untuk melakukan Penelitian Tindakan Kelas dengan memilih judul "Peningkatan Keterampilan Menulis Karangan Narasi dengan Menerapkan model Mind Mapping Siswa Sekolah Dasar (Penelitian Tindakan Kelas Pada Materi Menulis Karangan Narasi Siswa Kelas IVB SDN 007 Bangkinang Kecamatan Bangkinang Kota Kabupaten Kampar Tahun Ajaran 2007/2017)".

Tujuan Penelitian penelitian tindakan adalah untuk peningkatan keterampilan menulis siswa kelas IVB SDN 007 Bangkinang. Tujuan khusus penelitian tindakan kelas ini adalah:

1. Untuk mendiskripsikan peningkatan aktivitas guru dalam mengajar pelajaran bahasa Indonesia materi karangan narasi melalui model pembelajaran Mind Mapping pada siswa kelas IVB SD Negeri 007 Bangkinang.

2. Untuk mendiskripsikan peningkatan aktivitas siswa dalam pembelajaran bahasa Indonesia materi karangan narasi melalui model pembelajaran Mind Mapping pada siswa kelas IVB SD Negeri 007 Bangkinang.

3. Untuk mengetahui hasil keterampilan menulis bahasa Indonesia dengan menggunakan Mind Mapping. 


\section{METODE PENELITIAN}

Jenis penelitian ini adalah penelitian tindakan kelas (PTK). Menurut Kurt Lewin (dalam Kunandar, 2011:42) penelitian tindakan kelas adalah "suatu rangkaian langkah yang terdiri atas empat tahap, yakni perencanaan, tindakan, pengamatan, dan refleksi”.

Melalui PTK guru dapat mengembangkan model-model mengajar yang bervariasi, pengelolaan, kelas yang dinamis dan kondusif, serta penggunaan media dan sumber belajar yang tepat dan memadai. Dengan penerapan hasilhasil PTK secara berkesinambungan diharapkan PBM di sekolah (kelas) tidak kering dan membosankan serta menyenangkan siswa.

Pada intinya tujuan utama PTK bertujuan untuk "memperbaiki berbagai persoalan nyata dan praktis dalam peningkatan mutu pembelajaran di kelas yang dialami langsung dalam interaksi antara guru dengan siswa yang sedang belajar" (Arikunto, 2014:60).

Tempat penelitian ini dilaksanakan di kelas IVB SD Negeri 007 Bangkinang Kecamatan Bangkinang Kota Kabupaten Kampar. Waktu penelitian ini dilaksanakan bulan April-Juni. Subjek penelitian ini adalah guru, observer, dan siswa kelas IVB SD Negeri 007 Bangkinang yang berjumlah 22 orang, yang terdiri dari 12 orang laki-laki dan 10 orang perempuan. Peneliti mengambil subjek penelitian di kelas
IVB karena permasalahan pembelajaran bahasa Indonesia materi menulis karangan narasi merupakan permasalahan yang terdapat pada $\begin{array}{llll}\text { siswa kelas IVB SDN } 007 & \end{array}$ Bangkinang.

Penelitian ini dilakukan dalam dua siklus, siklus pertama terdiri dari perencanaan, pelaksanaan, pengamatan, refleksi, dan siklus ke dua juga demikian terdiri dari perencanaan, pelaksanaan, pengamatan dan refleksi.

Data dalam penelitian ini diperoleh melalui: 1) observasi, untuk mengamati aktivitas guru dan siswa selama proses pembelajaran dengan menerapkan model pembelajaran Mind Mapping, 2) tes, dilakukan untuk mengetahui hasil belajar siswa setelah tindakan siklus I dan siklus II, 3) dokumentasi, teknik dokumentasi digunakan untuk menampilkan foto tentang kegiatan belajar mengajar dengan model pembelajaran Mind Mapping.

Pengumpulan data penelitian dilakukan dengan hasil menulis karangan narasi siswa.Hasil menulis karangan narasi siswa untuk melihat sejauh mana ketuntasan dalam menggunakan model Mind Mapping dalam menulis karangan narasi. Untuk mengetahui hasil keterampilan siswa dengan cara memberikan latihan kepada siswa, latihan yang diberikan berkaitan dengan tujuan penelitian yang hendak dicapai. 
1. Teknik Tes (tertulis)

Pengumpulan data penelitian melakukan LKS dan evaluasi (ulangan harian) yang dilkukan pada kegiatan inti dan ulangan pada kegiatan pada setiap siklus. Berdasarkan hasil menulis karangan narasi siswa dianalisis untuk memperoleh data hasil peningkatan keterampilan siswa dalam menulis karangan narasi.

\section{Teknik Pengamatan (nontes)}

Pengamatan (nontes) digunakan untuk melakukan pengamatan terhadap pelaksanaan tindakan yang diberikan guru dalam proses pembelajaran pengamatan ini ditujukan pada guru dan siswa, pengamatan menggunakan lembaran aktivitas guru dan aktivitas siswa.

Data yang diperoleh dari hasil belajar siswa akan dikumpulkan dan kemudian dianalisa dengan menggunakan analisis statistik kualitatif yang diperoleh melalui dua siklus. Selanjutnya dianalisis dengan cara menghitung jumlah nilai hasil evaluasi masing-masing dalam satu kelas kemudian jumlah dihitung dalam persentase. Untuk memperoleh aktivitas guru dan siswa diperoleh dengan menggunakan rumus:

$$
N R \frac{J S}{S M} x 100
$$

Keterangan:

$\mathrm{NR}=$ Persentasi rata-rata aktivitas

JS = Jumlah skor aktivitas siswa yang dilakukan
$\mathrm{SM}=$ Skor maksimal yang didapat dari aktivitas.

Tabel 3.2 Kategori Aktivitas Siswa dan Guru

\begin{tabular}{|c|c|c|}
\hline No & $\begin{array}{c}\% \\
\text { Interval }\end{array}$ & Kategori \\
\hline 1. & $90-100 \%$ & Baik sekali \\
\hline 2. & $80-89 \%$ & Baik \\
\hline 3. & $70-79 \%$ & Cukup \\
\hline 4. & $60-69 \%$ & Kurang \\
\hline 5. & $<60$ & $\begin{array}{c}\text { Sangat } \\
\text { kurang }\end{array}$ \\
\hline
\end{tabular}

Modifikasi Tim Pustaka Yustisia (irawati, 2015:30-31)

1. Keterampilan siswa Menulis Karangan Narasi

Untuk mengetahui keterampilan menulis karangan narasi siswa, peneliti menggunakan tes tertulis. Indikator yang dinilai dalam keterampilan menulis karangan narasi siswa sebagai berikut yang menggunakan penilaian dari rubrik.

Tabel 3.4 Kategori Keterampilan Menulis Karangan Narasi Siswa SDN 003 Bangkinang

\begin{tabular}{|c|c|c|}
\hline No & \% Interval & Kategori \\
\hline 1. & $90-100 \%$ & Baik sekali \\
\hline 2. & $80-89 \%$ & Baik \\
\hline 3. & $70-79 \%$ & Cukup \\
\hline 4. & $60-69 \%$ & Kurang \\
\hline 5. & $<60$ & $\begin{array}{l}\text { Sangat } \\
\text { kurang }\end{array}$ \\
\hline
\end{tabular}

2. Ketuntasan Individu

Ketuntasan siswa secara individu dapat dilihat dari hasil menulis karangan narasi siswa yang telah diperiksan oleh guru dari hasil 
pertemuan pada setiap tindakan. Ketuntasan belajar secara individu apabila siswa memperoleh nilai KKM yang ditetapkan oleh sekolah. KKM yang ditetapkan sekolah untuk pelajaran bahasa Indonesia adalah 75 .

\section{Ketuntasan Klasikal}

Siswa dikatakan tuntas apabila nilainya sama dengan KKM atau lebih tinggi dari KKM yaitu 75 . Sedangkan ketuntasan secara klasikal dikatakan tuntas apabila $85 \%$ dari seluruh siswa memperoleh nilai minimal 75. Untuk menentukan ketuntasan secara klasikal rumus yang digunakan yaitu (Sumarni 2012:226) :

$$
\begin{aligned}
& \text { Ketuntasan Klasikal } \\
& =\frac{\text { jumlah siswa yang tuntas }}{\text { jumlah seluruh siswa }} \times 100
\end{aligned}
$$

\section{HASIL DAN PEMBAHASAN}

Aktivitas guru dalam proses belajardapat diamati dengan menggunakan lembar observasi pada tiap kali pertemuan yang dilakukan oleh seorang observer. Hasil rata-rata aktivitas guru tersebut dapat dilihat pada tabel berikut ini:

\section{Hasil Pengamatan Aktivitas Guru Siklus I}

\begin{tabular}{|c|c|c|}
\hline Pertemuan & Persentase & Kategori \\
\hline I (pertama) & $65,71 \%$ & Kurang \\
\hline II (kedua) & $74,28 \%$ & Cukup \\
\hline Rata-rata & $70 \%$ & Cukup \\
\hline
\end{tabular}

Adapun kesimpulan dari kegiatan guru pada pertemuan pertama dan kedua siklus I ini menunjukkan adanya peningkatan, hal ini dapat dilihat pada pertemuan pertama jumlah nilai kegiatan aktivitas guru adalah dengan persentase $65,71 \%$ dan dikategorikan "kurang". Sedangkan pada pertemuan kedua jumlah nilai aktivitas guru adalah dengan persentase sebesar $74,28 \%$ dan dikategorikan "cukup", dari kedua pertemuan tersebut terdapat rata-rata sebesar $70 \%$ dengan kategori "cukup".

Hasil pengamatan aktivitas siswa siklus I, secara keseluruhuan rata-rata aktivitas siswa pada siklus I adalah $61 \%$ dengan kategori kurang. Aktivitas siswa dengan penerapan model pembelajaran Mind Mapping pada siklus I dapat dilihat pada tabel berikut:

Hasil Pengamatan Aktivitas Siswa Siklus I

\begin{tabular}{|c|c|c|}
\hline Pertemuan & Persentase & Kategori \\
\hline I (pertama) & $57,14 \%$ & $\begin{array}{c}\text { Sangat } \\
\text { kurang }\end{array}$ \\
\hline II (kedua) & $65,71 \%$ & Kurang \\
\hline Rata-rata & $61,42 \%$ & Kurang \\
\hline
\end{tabular}

Adapun kesimpulan dari kegiatan siswa pada pertemuan pertama dan kedua siklus I ini menunjukkan adanya peningkatan yang baik, hal ini dapat dilihat pada pertemuan pertama jumlah nilai kegiatan aktivitas siswa adalah dengan persentase $57,14 \%$ dan dikategorikan "sangat kurang". Sedangkan pada pertemuan kedua 
jumlah nilai aktivitas siswa dengan persentase $65,71 \%$ dan dikategorikan "kurang", dari kedua pertemuan tersebut terdapat rata-rata sebesar $61,42 \%$

\section{Keterampilan Menulis Karangan} Narasi Siswa Siklus I

Keterampilan menulis karangan narasi siswa kelas IVB SDN 007 Bangkinang pada siklus I dapat dilihat pada tabel rekapitulasi berikut ini:

\section{Keterampilan Menulis Karangan Narasi Siswa Siklus I}

\begin{tabular}{|l|c|c|}
\hline Kategori & $\begin{array}{l}\text { Jumlah } \\
\text { siswa }\end{array}$ & Persentase \\
\hline Sangat baik & - & - \\
\hline Baik & 14 siswa & $63,63 \%$ \\
\hline Cukup & 4 siswa & $18,18 \%$ \\
\hline Kurang & 3 siswa & $13,63 \%$ \\
\hline Sangat kurang & 1 siswa & $4,54 \%$ \\
\hline Rata-rata & & 78,72 \\
\hline Siswa tuntas & 17 siswa & $77,27 \%$ \\
\hline $\begin{array}{l}\text { Siswa tidak } \\
\text { tuntas }\end{array}$ & 5 siswa & $22,72 \%$ \\
\hline $\begin{array}{l}\text { Ketuntasan } \\
\text { klasikal }\end{array}$ & $85 \%$ & $77,27 \%$ \\
\hline Kategori & \multicolumn{2}{|c|}{ Cukup } \\
\hline
\end{tabular}

Berdasarkan tabel di atas dapat diketahui bahwa pada pelaksanaan tes siklus I nilai rata-rata kelas mencapai 78,72. Sesuai indikator keberhasilan bahwa siswa dikatakan tuntas belajar, jika siswa memperoleh nilai $\geq 75$. Jika kurang dari 75, maka siswa tersebut dikatakan tidak tuntas belajar. Berdasarkan hasil ulangan harian siklus I terdapat 5 orang siswa yang tidak tuntas dan 17 siswa yang tuntas. Dan dengan ketuntasan klasikal belajar sebesar 77,27\%. Jika dilihat dari ketuntasan belajar klasikal 85\% maka hasil ulangan harian siklus
I belum berhasil maka peneliti akan melakukan perbaikan pembelajaran pada siklus II.

\section{Refleksi Siklus I}

Setelah melakukan tindakan siklus I guru dan observer melakukan diskusi tentang tindakan yang telah dilakukan, hal yang didiskusikan adalah tentang kelemahan-kelemahan yang telah dilakukan pada siklus I pertemuan pertama dan pertemuan kedua. Penerapan model pembelajaran Mind Mapping pada materi menulis karangan narasi pada siklus I belum menunjukkan adanya keberhasilan yang memuaskan bagi peneliti. Ketidakpuasan tersebut disebabkan oleh perolehan hasil pengukuran terhadap aktivitas guru, aktivitas siswa dan keterampilan menulis karangan narasi siswa yang masih belum maksimal. Adapun refleksi pada siklus I adalah guru tidak melakukan tanya jawab dan mengomentari hasil kerja siswa dan membimbing siswa membuat kerangka karangan. Upaya yang dapat peneliti lakukan untuk meningkatkan aspek kegiatan pembelajaran yakni dengan memberikan kesempatan kepada siswa untuk melakukan tanya jawab dengan siswa dan komentar hasil kerja siswa, membimbing siswa membuat kerangka karangan sehingga siswa mengerti dan memahami pembelajaran. 
Hasil Penelitian Siklus II

1. Hasil Pengamatan Aktivitas Guru Siklus II

Hasil rata-rata aktivitas guru pada siklus II dapat dilihat pada tabel berikut:

\section{Hasil Pengamatan Aktivitas Guru} Siklus II

\begin{tabular}{|c|c|c|}
\hline Pertemuan & Persentase & Kategori \\
\hline I (pertama) & $82,85 \%$ & Baik \\
\hline II (kedua) & $94,28 \%$ & $\begin{array}{c}\text { Sangat } \\
\text { baik }\end{array}$ \\
\hline Rata-rata & $88,57 \%$ & Baik \\
\hline
\end{tabular}

Adapun kesimpulan dari kegiatan guru pada pertemuan pertama dan kedua siklus II ini telah menunjukkan adanya peningkatakan yang sangat baik, hal ini dapat dilihat dari jumlah hasil persentase pada pertemuan pertama sebesar $82,85 \%$ dengan kategori "baik" dan mengalami peningkatan pada pertemuan kedua dengan hasil persentase sebesar 94,28\% dengan kategori "sangat baik". dari kedua pertemuan tersebut terdapat rata-rata sebesar $88,57 \%$.

\section{Hasil Pengamatan Aktivitas Siswa} Siklus II

Hasil pengamatan aktivitas siswa siklus II dengan menerapkan model pembelajaran Mind Mapping dapat dilihat pada tabel berikut:

\section{Hasil Pengamatan Aktivitas Siswa} Siklus II

\begin{tabular}{|c|c|c|}
\hline Pertemuan & Persentase & Kategori \\
\hline I (pertama) & $77,14 \%$ & Cukup \\
\hline II (kedua) & $94,28 \%$ & Sangat baik \\
\hline Rata-rata & $85,71 \%$ & Baik \\
\hline
\end{tabular}

Adapun kesimpulan dari kegiatan siswa pada pertemuan pertama dan kedua siklus II ini menunjukkan adanya peningkatan yang baik, hal ini dapat dilihat pada pertemuan pertama jumlah nilai kegiatan aktivitas siswa adalah dengan persentase $77,14 \%$ dan dikategorikan "cukup". Sedangkan pada pertemuan kedua jumlah nilai aktivitas siswa dengan persentase 94,28\% dan dikategorikan "sangat baik", dari kedua pertemuan tersebut terdapat rata-rata sebesar $85,71 \%$ dengan kategori "baik ".

3. Keterampilan Menulis Karangan Narasi Siklus II

Setelah pelaksanaan tindakan selesai dilakukan, maka dilakukan ulangan harian untuk mengukur kemampuan siswa dalam pembelajaran bahasa Indonesia materi menulis karangan narasi. Hasil tes keterampilan menulis yang dilakukan siswa setelah proses pembelajaran siklus II dapat dilihat dari tabel berikut:

\section{Hasil Keterampilan Menulis Siklus II Kelas IVB SDN 003 Bangkinang}

\begin{tabular}{|c|c|c|}
\hline Kategori & Pratindakan & Persentase \\
\hline Sangat baik & 1 siswa & $4,54 \%$ \\
\hline Baik & 17 siswa & $72,27 \%$ \\
\hline Cukup & 2 siswa & $9,09 \%$ \\
\hline Kurang & 2 siswa & $9,09 \%$ \\
\hline $\begin{array}{l}\text { Sangat } \\
\text { kurang }\end{array}$ & - & - \\
\hline Rata-rata & 19 siswa & $86,36 \%$ \\
\hline Siswa tuntas & 3 siswa & $13,63 \%$ \\
\hline $\begin{array}{l}\text { Siswa tidak } \\
\text { tuntas }\end{array}$ & $85 \%$ & $86,36 \%$ \\
\hline $\begin{array}{l}\text { Ketntasan } \\
\text { klasikal }\end{array}$ & & Sangat Baik \\
\hline Kategori & & 84,5 \\
\hline
\end{tabular}


Berdasarkan tabel di atas, dapat diketahui data hasil belajar siswa pada siklus II menunjukkan adanya peningkatan hasil belajar siswa dari siklus I ke siklus II yaitu jumlah nilai rata-rata siklus II 82,54 dan dengan ketuntasan klasikal $86,36 \%$. Maka dapat dikatakan pelaksanaan pembelajaran dengan menerapkan model pembelajaran Mind Mapping dapat meningkatkan keterampilan menulis karangan narasi bahasa Indonesia siswa kelas IVB SDN 003 Bangkinang.

\section{Refleksi Siklus II}

Setelah melakukan tindakan dan diamati oleh observer selanjutnya peneliti melakukan refleksi untuk melihat kesalahan-kesalahn yang terjadi pada siklus II. Pada siklus II ini proses pembelajaran sudah lebih baik dibandingkan siklus I. Diketahui bahwa siswa yang tuntas mencapai 19 orang siswa atau dengan persentase $86,36 \%$. Jumlah siswa yang tuntas sangat meningkat yaitu dari 16 orang $(72,72 \%)$ menjadi 2 orang $(86,36 \%)$. Artinya keterampilan menlis karangan narasi siswa pada siklus II telah melebihi $85 \%$ mencapai Kriteria Ketuntasan Minimal yang telah ditetapkan.

Adapun Kriteria Ketuntasan Minimal (KKM) yang telah ditetapkan dalam penelitian ini adalah 75. Keberhasilan ini disebabkan guru dan siswa telah melaksanakan model pembelajaran Mind Mapping dengan benar dan tepat. Untuk itu, peneliti tidak perlu melakukan siklus berikutnya, karena sudah jelas keterampilan menulis karangan narasi yang diperoleh.

\section{Aktivitas Guru}

Pada siklus I diketahui bahwa nilai aktivitas guru yang diperoleh peneliti yaitu $65,71 \%$ pada pertemuan pertama dan $74,28 \%$ pada pertemuan kedua. Rata-rata nilai perolehan pada siklus I adalah sebesar $70 \%$ yang berada pada kategori cukup. Namun, peneliti harus meningkatkan kembali aktivitas guru dalam mengajar, karena masih banyak terjadi kekurangan dalam melakukan proses dalam pelaksanaan pembelajaran. Perbaikan tersebut dlakukan guna meningkatkan kemampuan guru dalam melaksanakan pemelajaran dan meningkatkan hasil keterampilan menulis karangan narasi siswa sehingga dapat mencapai indikator atau tujuan pembelajaran yang telah ditetapkan, baik dalam pelaksaan pembelajaran dan penerapan model Mind Mapping. Perbaikan yang akan dilakukan guru yaitu pada aspek memberikan kesempatan bertanya kapada siswa yang masih mendapat nilai rendah, serta memberikan kesempatan kepada siswa untuk menganalisa media gambar yang telah disediakan dan guru memberikan bimbingan yang lebih optimal dalam mengajar.

Hasil perolehan aktvitas guru pada siklus II mengalami peningkatan dalam pelaksaan pembelajaran. 
Peneliti memperoleh nilai aktivitas guru pada pertemuan 1 sebesar $82,85 \%$ dan pertemuan 2 sebesar $94,28 \%$. Hal ini telah menunjukkan keberhasilan, karena kekurangankekurangan yang terjadi pada siklus sebelumnya telah berhasil diperbaiki dengan baik oleh guru. Dengan memaksimalkan waktu pembelajaran dan menerapkan secara maksimal langkah-langkah pembelajaran yang telah disiapkan dalam rencana pelaksanaan pembelajaran sehingga aktivitas guru meningkat.

Lebih jelasnya dapat dilihat pada tabel berikut :

\section{Perbandingan Aktivitas Guru} Siklus I Dan Siklus II

\begin{tabular}{|c|c|c|c|}
\hline No. & Siklus & Persentase & Keterangan \\
\hline 1 & Siklus I & $70 \%$ & Cukup \\
\hline 2 & Siklus II & $88,57 \%$ & Baik \\
\hline
\end{tabular}

\section{Aktivitas Siswa}

Perolehan yang mengukur hasil aktivitas siswa pada siklus I selama proses pembelajaran menunjukkan persentase hasil observasi aktivitas siswa pada pertemuan 1 sebesar $57,14 \%$ dan pertemuan 2 sebesar $65,71 \%$. dari kedua pertemuan tersebut didapatkan persentase rata-rata sebesar $61,42 \%$, angka tersebut dikategori "Kurang" walaupun demikian diperlukan perbaikan dalam pembelajaran pada siklus II agar aktivitas siswa dapat meningkat ada 3 aspek yang nilainya masih rendah yaitu rendahnya perhatian siswa saat guru menjelaskan materi pelajaran, keaktifan siswa dalam mengajukan pertanyaan kepada guru, dan membuat kerangka karangan dengan menambahkan kata tanya pada setiap cabang peta kerangka karangan.

Perbaikan yang akan dilaksanakan yaitu membuat siswa lebih memperhatikan penjelasan guru, siswa berperan aktif bertanya kepada guru, dan memberikan banyak kesempatan kepada siswa untuk dan lebih kepada siswa agar siswa terpancing untuk memperhatikan dan bertanya serta dengan berani mengemukakan pendapatnya.

Aktivitas belajar siswa pada siklus II mengalami peningkatan yang sangat bagus jika dibandingkan dengan siklus I, hal ini dapat dilihat dari hasil observasi aktivitas siswa pada siklus II pertemuan 1 sebesar $77,14 \%$ dan siklus II pertemuan 2 sebesar 94,28\%. Dari kedua pertemuan tersebut didapatkan persentase rata-rata sebesar $85,71 \%$. Hasil aktivitas siswa mengalami peningkatan dari siklus I $61,42 \%$ ke siklus II 85,71\%.

Lebih jelasnya dapat dilihat pada tabel berikut ini:

\section{Perbandingan Aktivitas Siswa} Siklus I dan Siklus II

\begin{tabular}{|c|c|c|c|}
\hline No & Siklus & Persentase & Keterangan \\
\hline 1 & Siklus I & $61,42 \%$ & Kurang \\
\hline 2 & Siklus II & $85,71 \%$ & Baik \\
\hline
\end{tabular}


3. Keterampilan Menulis Karangan

Dengan Model Mind Mapping

Diketahui bahwa jumlah siswa kelas IVB SDN 007 Bangkinang sebanyak 22 siswa, dan yang mencapai nilai KKM (75) sebanyak 17 siswa dengan persentase $77,27 \%$ dari 22 siswa pada siklus I, dalam hal ini telah terjadi peningkatan hasil keterampilan menulis karangan narasi siswa dari sebelum terjadinya tindakan, namun masih ada 5 siswa yang belum mencapai nilai KKM, salah satu penyebabnya adalah terdapatnya beberapa kekurangan yang dilakukan saat proses pembelajaran dan masih adanya siswa yang kebingungan ketika proses pembelajaran.

Pada siklus ini guru masih belum mnguasai langkah-langkah pembelajaran Mind Mapping sehingga mengalami beberapa kelemahan, khususnya adalah guru terburu-buru dalam menjelaskan pembelajaran, kurangnya aktivitas tanya jawab dilakukan dengan siswa, begitu juga dengan siswa yang belum memahami apa yang disampaikan guru, sehingga apa yang mereka tulis tidak sesuai dengan yang diharapkan.

Perolehan hasil Ulangan Harian (UH) II pada siklus II menunjukkan adanya peningkatan, baik dari nilai rata-rata yang mencapai 82,54\%, perolehan ini sudah mencapai kriteria yang ditentukan dengan ketuntasan klasikal 85\%. Dan siswa yang belum mencapai kriteria ketuntasan minimal
(KKM) 75 jumlahnya semakin berkurang. Yang mana pada siklus I terdapat 5 siswa yang belum mencapai KKM dan pada siklus II yang belum mencapai KKM menjadi 3 orang siswa. Hal ini menunjukkan telah berhasilnya pembelajaran keterampilan menulis karangan narasi siswa pada siklus II. Lebih jelasnya dapat dilihat pada tabel berikut ini:

Perbandingan Hasil Keterampilan Menulis Karangan Narasi Bahasa Indonesia

\begin{tabular}{|l|l|c|c|c|}
\hline No & Keterangan & $\begin{array}{l}\text { Data } \\
\text { awal }\end{array}$ & Siklus I & Siklus II \\
\hline 1 & $\begin{array}{l}\text { Nilai rata- } \\
\text { rata }\end{array}$ & 71,27 & 78,72 & 82,54 \\
\hline 2 & $\begin{array}{l}\text { Persentase } \\
\text { ketuntasan } \\
\text { klasikal }\end{array}$ & $40,90 \%$ & $77,27 \%$ & $86,36 \%$ \\
\hline
\end{tabular}

Berdasarkan analisis data pelaksanaan tindakan pada siklus II pembelajaran yang dilakukan dapat dikatakan berhasil karena seluruh aspek yang diteliti telah memenuhi indikator keberhasilan. Dengan demikian, dapat disimpulkan bahwa aktivitas guru, aktivitas siswa dapat ditingkatkan dengan menggunakan model pembelajaran Mind Mapping.

$$
\text { Menurut Buzan (dalam }
$$

Taufik, 2012 : 349) "Mind Mapping adalah cara mencatat yang kreatif, efektif, dan secara harfiah akan memetakan pikiran-pikiran kita.

\section{SIMPULAN}

Berdasarkan hasil analisis data dan pembahasan yang telah dipaparkan pada Bab IV, peneliti dapat menyimpulkan bahwa 
penerapan pembelajaran Mind Mapping dapat meningkatkan aktivitas guru, aktivitas dan hasil keterampilan menulis karangan narasi siswa kelas IVB SDN 007 Bangkinang pada mata pelajaran bahasa Indonesia, berikut hasil aktivitas guru, siswa dan hasil keterampilan menulis karangan narasi siswa.

\section{Hasil Observasi Aktivitas Guru}

Hasil observasi aktivitas guru dalam menerapkan model pembelajaran Mind Mapping selama dua siklus mengalami peningkatan pada setiap setiap siklus, pada siklus I pertemuan pertama guru mendapatkan nilai $65,71 \%$, pada pertemuan kedua $74,28 \%$. Sementara pada siklus II pertemuan pertama mendapat nilai $82,85 \%$ pada pertemuan kedua 94,28 , dengan demikian terjadi peningkatan dari siklus I ke siklus II. Dari hasil kedua siklus tersebut, dapat diketahui bahwa model pembelajaran Mind Mapping mampu meningkatkan aktivitas guru dalam merenca-nakan dan melaksanakan pembelajaran.

\section{Hasil Observasi Aktivitas Siswa}

Dari hasil observasi terhadap akivitas siswa selama pembelajaran, dapat diketahui bahwa aktivitas siswa mengalami peningkatan disetiap siklus I pertemuan pertama $57,14 \%$, pada pertemuan kedua yaitu $65,71 \%$. Sementara itu pada siklus II pertemuan pertama $77,14 \%$, pada pertemuan kedua yaitu 94,28\%. Hal ini menunjukkan bahwa model pembelajaranMind Mapping dapat meningkatkan aktivitas siswa dalam pembelajaran.

3. Hasil Keterampilan Menulis Karangan Narasi Siswa

Setelah peneliti menerapkan model pembelajaran Mind Mapping, hasil keterampilan menulis karangan narasi siswa yang terdiri dari ketuntasan belajar klasikal dan ratarata nilai dapat meningkat disetiap siklus. Pada siklus I, persentase ketuntasan klasikal 77,27\% dengan rata-rata nilai 78,72 . Dan pada siklus II, ketuntasan belajar klasikal mencapai $86,36 \%$ dengan rata-rata nilai 82,54, dari kedua hasil belajar tersebut, dapat diketahui bahwa persentase ketuntasan belajar klasikal meningkat sebanyak $9,09 \%$ dan ratarata nilai meningkat sebesar 4,54.

\section{DAFTAR RUJUKAN}

Arikunto, Suharsimi dkk. (2014). Penelitian Tindakan Kelas.Jakarta: PT Bumi Aksara.

Aritonang, Keke T. (2008). Pendidikan Penabur; Minat dan Motivasi dalam Meningkatkan Hasil Belajar Siswa. 10 (7), hlm 1.

Dian, Dinarti. (2013). Peningkatan Kemampuan Menulis Puisi Melalui Metode Peta Pikiran (Mind Mapping) Pada Siswa Kelas IV. Universitas Muhamadiyah. Surakarta: 
Skripsi

Dipublikasikan.

Ikhwanuddin Arif. (2013). Penerapan metode Mind Mapping untuk meningkatkan keterampilan menulis karangan narasi siswa kelas $S D$. Universitas Negeri Semarang. Semarang: Skripsi Tidak Dipublikasikan.

Irawati. (2015). Peningkatan Hasil Belajar Pendidikan Kewarganegaraan Melalui Pembelajaran Kooperatif Tipe Numbered Head Together (NHT) Pada Siswa $S D$. STKIP YPTT Riau. Bangkinang: Skripsi Tidak Dipublikasikan.

Mulyati, Yeti dkk. (2008).

Keterampilan Berbahasa

Indonesia SD. Jakarta:

Universitas Terbuka.

Nugraheni Sri. (2012). Pengajaran Bahasa Indonesia Berbasis Karakter. Yogyakarta: Mentari Pustaka.

Nurgiyantoro Burhan. (2010). Penilaian Pembelajaran Bahasa. Yogyakarta: BPFEYogyakarta .

Purwanto. (2014). Evaluasi Hasil Belajar. Surakarta: Pustaka Belajar.

Rich Dhorothy. (2008). Pengajaran Dan Bimbingan Kelas 4-6 SD. Jakarta: PT Indeks.

Sri Sumarni. (2012). Metodologi Penelitian Pendidikan. Yogyakarta: Insan Madani.
Supriadie Didi dan Deni Darmawan. (2012).

Komunikasi Pembelajaran. Bandung: PT Remaja Rosdakarya.

Tarigan, Heny Guntur. (2007). Metodologi Pengajaran Bahasa 2. Bandung: Angkasa Bandung.

Taufik, Taufina. (2012). Mozaik Pembelajaran Inovatif. Padang: Suka Bina Press. 